\title{
Hydrodynamic Characteristics of the Continental Intercalaire and Continental Hamadien Aquifer Systems in the Iullemeden Basin of Tahoua Region Republic of Niger
}

\author{
Abdel Kader Hassane Saley, ${ }^{1 *}$, Issoufou Sandao', Jean-Luc Michelot ${ }^{2}$, Boureïma Ousmane1 \\ ${ }^{1}$ Department of Geology, Groundwater and Georesources Laboratory, Faculty of Sciences and Technology, Abdou Moumouni \\ University of Niamey, Niamey, Niger \\ ${ }^{2}$ Geosciences Laboratory Paris-Sud (GEOPS), University Paris-Sud (UPS), University Paris-Saclay, Orsay Cedex, France \\ Email: `hassanesaleyak@gmail.com
}

How to cite this paper: Saley, A.K.H., Sandao, I., Michelot, J.-L. and Ousmane, B. (2019) Hydrodynamic Characteristics of the Continental Intercalaire and Continental Hamadien Aquifer Systems in the Iullemeden Basin of Tahoua Region Republic of Niger. Journal of Water Resource and Protection, 11, 1188-1205.

https://doi.org/10.4236/jwarp.2019.119069

Received: August 17, 2019

Accepted: September 23, 2019

Published: September 26, 2019

Copyright $\odot 2019$ by author(s) and Scientific Research Publishing Inc. This work is licensed under the Creative Commons Attribution International License (CC BY 4.0).

http://creativecommons.org/licenses/by/4.0/

\begin{abstract}
This study was conducted in the region of Tahoua the northeastern part of the Southern Illulemeden sedimentary basin. In this region the transboundary aquifer system of Continental Intercalaire (CI) and the Continental Hamadien $(\mathrm{CH})$ are potentially rich in underground water especially in free and captive aquifers. More, this water is the main source of drinking water for the populations, the animals and for agriculture and extractive industries. However, the population growth, the agricultural development, and the climate change have a real impact on the dynamics of groundwater and the exploitation of these resources. Hence, this study aims at analyzing the behavior of aquifers and assessing the impact of various natural and anthropogenic factors. Especially it matters to analyze the drilling parameters and cuttings, logging data and pumping test of nine new boreholes. The results reveal that the depths equipped with boreholes catching the $\mathrm{CI} / \mathrm{CH}$ complex vary from 70 to 800 meters from East to West while the average thickness of the reservoir $\mathrm{CH}$ is 50 meters and it mainly consists of coarse sandstone. Drilling penetrated more than 100 meters into the CI without reaching the base. The $\mathrm{CI}$ tank is composed of several layers of gravel and clay whilst the $\mathrm{CI} / \mathrm{CH}$ aquifers flow rates range from 0.2 to $22.8 \mathrm{~m}^{3} / \mathrm{h} / \mathrm{m}$. So this is cause of great variability of the water potential within this aquifer. Lastly, the transmissivity coefficients are more important in the $\mathrm{CH}$ than in the CI, and the water flow average rates range respectively from $29 \mathrm{~m} /$ year to $7 \mathrm{~m} /$ year.
\end{abstract}




\section{Keywords}

Iullemeden Basin, Continental Intercalaire/Continental Hamadien, Niger, Tahoua, Hydrogeology, Hydrodynamics

\section{Introduction}

In the Tahoua Region of central Niger, the multi-continental trans-continental aquifer of Continental Intercalaire/Continental Hamadien has significant water potential [1] [2] [3] [4]. It is the main source of drinking water for people and animals, and it also provides water for irrigation and extractive industries. Recurring droughts from the 1970s to today in the region [5] [6] [7] [8] [9], population growth and the increasing number of livestock [10], the development of irrigation and extractive industries are factors likely to affect the quantity and quality of water resources in the $\mathrm{CI} / \mathrm{CH}$ aquifer system. In fact, knowledge is still limited to these potentials, despite the work and studies carried out [4] [11]-[19] [20]. This is evidenced by the recent research by [19], which indicates that the current level of knowledge of the Iullemeden Aquifer System, regarding recharge areas, outflows, available resources and flow characteristics, is very uncertain. The main objective of this study was to contribute to a better knowledge of the $\mathrm{CI} / \mathrm{CH}$ system. The specific objectives were to analyze the monitoring data of drilling achievements, to interpret measurements of logging and pumping tests and to process all the data acquired using technical software (ArcGis, Gesfor, Illustrator and Statistica).

\section{General}

\subsection{Study Area 1}

The region of Tahoua is one of the eight regions of Niger and it comprises twelve departments. This region is situated between $13^{\circ} 20^{\prime}$ and $18^{\circ} 40^{\prime}$ north Latitude and between $3^{\circ} 50^{\prime}$ and $7^{\circ}$ Longitude and it covers about $114,425 \mathrm{~km}^{2}$ (Figure 1).

\subsection{Climate and Hydrography}

The climate of the Tahoua region is of Sahel-Saharan type and it is characterized by two seasons; a dry season dominated by warm and dry winds. Hence the dry wind Harmattan blows from North and North-East while the during the rainy season the Monsson blows from South to South-West and a wet, rainy season, with monsoon winds coming from the Atlantic to the south and circulating to the northeast. A dry, dominated by warm and dry winds, the Harmattan. This climate is subdivided into three (3) sub-zones from north to south of the region which are:

- the Saharan sub-zone, north of latitude $17^{\circ}$ north latitude, is characterized by an annual cumulative rainfall of less than $150 \mathrm{~mm}$; 


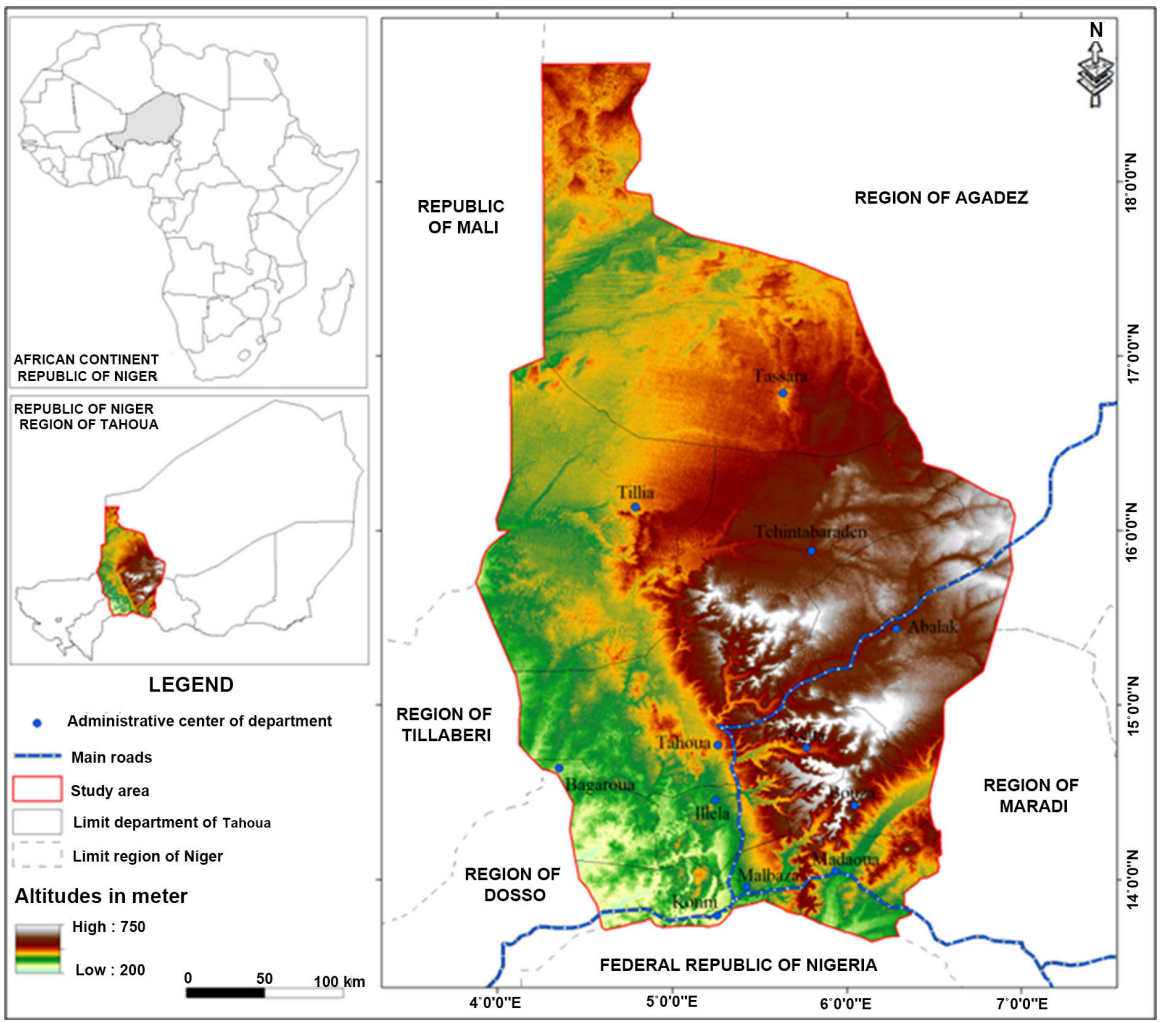

Figure 1. Location map of the study area.

- the Sahelo-Saharan sub-zone, located between $15^{\circ}$ and $17^{\circ}$ north latitude, and is characterized by an annual cumulative rainfall between 150 and 300 $\mathrm{mm}$. This is the domain of breeding;

- the Sahelian subzone, south of the 15th parallel of north latitude, with a rainfall of between 300 and $600 \mathrm{~mm}$. It is characterized by intense agro-sylvopastoral activity.

The hydrographic network is composed by broad valleys including: Tarka, Maggia, Badaguichiri Valley, Zourourou, Abalak, Tadiss, and Azaouak. They are active only during rainy seasons. There are also several temporary, semi-permanent and permanent ponds.

\subsection{Geology and Hydrogeology}

\subsubsection{Geology}

The geological context of the study area is characterized by five groups of sedimentary formations [11], which are bottom-up (Figure 2):

- Continental Cretaceous formations: the Continental Intercalaire (Neocomian to Albian) consists of fluvial, lacustrine and deltaic deposits. Its formations consist mainly of sandstones, clay sands and clays. There are silicified woods and remains of dinosaurs, crocodilians.

Above and in the southern part of the Continental Intercalaire lies the Continental Hamadian (Upper Cretaceous), consisting mainly of medium to coarse sandstones, more or less clayey; 


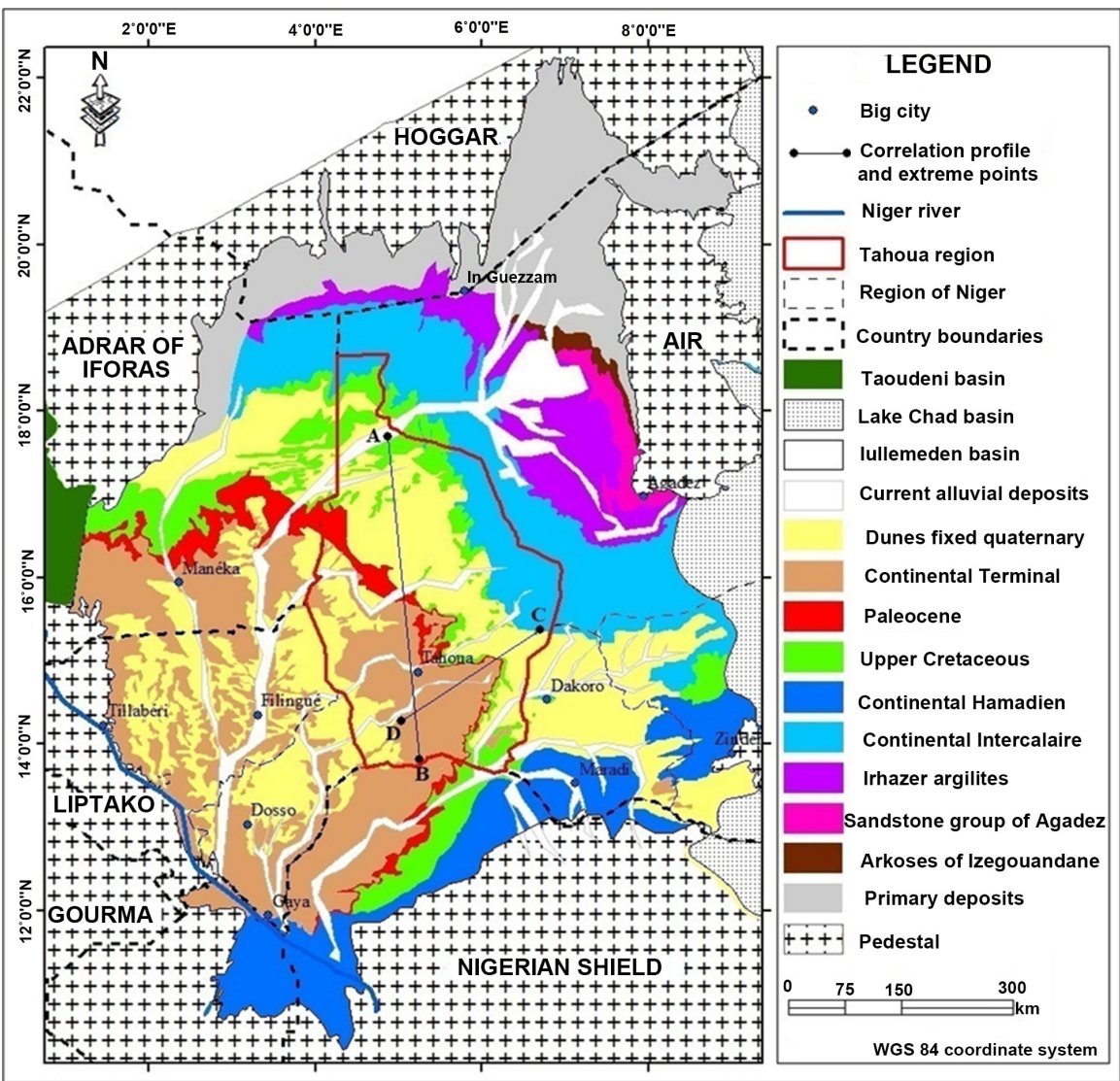

Figure 2. Geological map of the Iullemeden basin [21].

- The marine formations of the Upper Cretaceous: They consist of clays, calcareous sandstones, white limestones, gypsiferous clays, sea limestone alternations with foraminiferal and oyster debris, and continental limestones with gastropods, ostracodes, vertebrates dinosaurs, and finally there are fossiliferous marls;

- The marine formations of the Paleocene/Eocene: they consist of limestones, marl-limestones with operculinoids, marls and shales of thin thickness;

- Continental Cenozoic formations: called Continental Terminal [22], they are detritic, quartzo-kaolinic, siderolitic facies of middle post-Eocene and pre-Quaternary age. They are outcropping in the western and southwestern part of the study area;

- The Quaternary formations: these consist of fixed dunes covering indifferently the underlying formations (Cretaceous and Tertiary), living dunes in the northern part of the region, and alluvial deposits along the valleys [22].

\subsubsection{Hydrogeology}

We distinguish from bottom to top the following aquifers:

- The aquifer of Continental Intercalaire/Continental Hamadien, it is a transboundary aquifer system, shared between Niger, Mali, Nigeria and incidentally Benin. It has a great hydropower potential, it is very exploited for the 
water supply of the population [2]. This aquifer is open water to the east of the Tassara-Abalak axis and is collected at a shallow depth. On the other hand, it becomes captive in the rest of the region [1], with significant catchment depths;

- The aquifer of the Upper Cretaceous marine, it is of limited extension, flows are derisory with a strong mineralization of water. This aquifer is located mainly in the northern part of the Tahoua region and is not much used [1];

- The Paleocene aquifer, it is contained in limestone layers, of very limited extent, it is captured at shallow depth, and flow rates are very low;

- The Continental Terminal (CT) multilayer aquifer system, consisting of three layers, CT1 and CT2 which are captive and CT3 which is free. Only the CT1 and CT2 slicks can be exploited in the Tahoua region with flows that can be close to $20 \mathrm{~m}^{3} / \mathrm{h}$ locally;

- The Quaternary aquifers, with groundwater, are captured by shallow depths and by wells (cemented and traditional). They are easily accessible to people because of their shallow depths. However, these aquifers are very sensitive to pollution, linked to different human activities (intensive use of chemical fertilizers and pesticides).

\section{Material and Methods}

\subsection{Material}

The materials used in this study consist of data and tools. Accordingly, the data includes reports related to technical and lithological drill cuts, logging records, pumping tests, geological and hydrogeological maps, and digital terrain model (DTM) at 30 meters resolution. The study tools comprise logging recording blowers (compressor) and pumping tests (GRUNDFOS brand generator and pumps). In addition, the tools include various software; Gesfor, Adobe Illustrator CS6, ArcGis 10.2.2, Statistica and R.

\subsection{Methods}

The methodological approach adopted is the following:

\subsubsection{Acquisition of Data}

\section{- Collection of data}

The collection of data during this study was carried out at the technical documentation centers, in Niamey and in the interior of the country, with projects, NGOs, companies and consulting firms.

\section{- Collecting cuttings}

Samples or cuttings of different drilled layers were collected and analyzed in the field to establish the stratigraphic profile at each site.

\section{- Logs}

The procedure was to go down into the borehole before a probe reconnection connected to an electric cable, the latter was connected to a control device (Mi- 
crolloger). Three (3) parameters (resistivity, natural radioactivity and spontaneous polarization) were recorded according to depth in the form of logs. These parameters inform the nature of the layers (clays or sands) and water producing areas (saturated or unsaturated) with great precision.

\section{- Measurement of static levels}

Measurements of the static levels of the 9 new drillings were made immediately after the development and stabilization of the water level in the structures, in order to have reference levels. For other structures (wells and boreholes) with measuring ports, a static level measurement campaign was conducted using a sound probe in September 2016.

\section{- Pumping tests}

The pumping tests to determine the characteristics of the structures (maximum flow, maximum rabattement and pressure losses) and the hydrodynamic parameters of the aquifer (Transmissivity, permeability and storage coefficients) are as follows:

\section{$\checkmark$ Tiered test, determination of the characteristics of the structures}

These tests were carried out in stages of 2 hours each, at constant flow. The variation of the drawdown as a function of time was measured until the end of the landing. At the end of each 2 hours of pumping, a stop of a duration of 2 hours was observed, to make it possible to follow the rise of the level of water. Four stages were made by drilling, at increasing flow rates corresponding to $\mathrm{Q}$, $\mathrm{Q}_{1}\left(\mathrm{Q}_{1}=2 . \mathrm{Q}\right), \mathrm{Q}_{2}\left(\mathrm{Q}_{2}=3 . \mathrm{Q}\right)$ and $\mathrm{Q}_{3}\left(\mathrm{Q}_{3}=4 . \mathrm{Q}\right)$.

\section{$\checkmark$ Long-term test, determination of the hydrodynamic parameters of the aquifer}

The long-term pumping test was carried out continuously at a constant flow rate for 48 hours for drilling less than 400 meters deep (Doguérawa, Bouza, Keita, Tamaské, Ibohamane and Tassara) and for 72 hours for deep drilling. More than 400 meters (Konni, Illéla and Takanamat). The rise in the water level in each borehole was observed for a period of 12 hours after cessation of pumping. The drawdowns, during pumping and during the ascent, are raised.

\subsubsection{Data Processing}

\section{- Development of litho-stratigraphic logs}

The cuttings were analyzed by meter of depth and allowed the development of the litho-stratigraphic logs of the boreholes, using the GESFOR software.

Logging records and drilling rates of the different layers were also taken into account during this development of the logs. These litho-stratigraphic logs have been correlated with each other in north-south (A - B) and north-south to east-west (C - D) directions, in order to highlight the superimposition of the different geological formations and aquifers.

- Development of maps of static and piezometric levels

\section{$\checkmark$ Map of static levels}

The results of the static levels, measured at the end of the pumping tests and static levels for some structures with a system for raising static levels during 
September 2016 [4]. These data made it possible to map the static levels.

\section{$\checkmark$ Piezometric map}

This map was drawn from static water level surveys and altitudes of water points. Indeed, the piezometric coasts of the water levels in the structures were calculated by the difference between the altitudes of the water points (extracted at from the DTMs) and the value of the static level of each water point. The method of extracting altitudes from Digital Terrain Models (DTMs) was the following on ArcMap 10.2.2: "Arctoolbox" => "3D analyst tools" => "functional surface" $=>$ "add surface info" $=>$ ok.

The coasts, thus calculated, made it possible to elaborate the piezometric map of the Continental Intercalaire/Continental Hamadien aquifer system from the ArcGIS software.

\section{- Determination of transmissivity values}

To calculate the transmissivity coefficients, Jacob's method was used, equation (1). It consisted of carrying the values of the drawdown (s), measured during the long-term pumping tests, according to the logarithm of the pumping time $(t)$.Then, on the line obtained, the slope ( $i)$ of this line $s=f(\log t)$ and the time corresponding to the intersection of this line with the axis $s=0$ [23].

From the transmissivity values, the coefficient of permeability can be determined according to the relation $T=K \cdot e(K=$ coefficient of permeability and $e=$ power of the aquifer).

$$
T=\frac{0.183}{i} Q
$$

With,

T: coefficient of transmissivity $\left(\mathrm{m}^{2} / \mathrm{s}\right)$;

Q. pumping rate $\left(\mathrm{m}^{3} / \mathrm{h}\right)$;

$i$ : slope of the right.

\section{- Determination of groundwater flow velocities}

The flow velocity of water between two points, bore A (start) and drill B (finish), can be calculated according to Darcy's law, Equation (2):

$$
V=\frac{K \cdot i}{n e}
$$

With,

$V$ : water flow velocity $(\mathrm{m} / \mathrm{s})$;

$K$ : coefficient of permeability $(\mathrm{m} / \mathrm{s})$;

i: unit hydraulic gradient (without unit);

ne: effective porosity (without unit).

\section{Results and Discussion}

\subsection{Hydrogeological Parameters}

\subsubsection{Total Depths of Drilling}

The total depths of the holes in the Continental Intercalaire/Continental Hamadien aquifer system in the Tahoua region range from 70 meters to 799 meters 
from east to west, with an average of 330 meters and a standard deviation of 278 meters $(\mathrm{n}=290)$. In the free part of this $\mathrm{CI} / \mathrm{CH}$ system, east of the Tassara-Abalak axis, it is captured less than 100 meters deep (eg Abalak's $\mathrm{P}_{1}$ and $\mathrm{P}_{2}$ wells, Louberat drilling). On the other hand, to the west of the same axis, this aquifer system of the $\mathrm{CI} / \mathrm{CH}$ becomes captive, and the depths of capture range from more than 100 to 800 meters (including for example the drilling of Bouza, Konni, Takanamat).

The depths of the depths equipped with boreholes (Figure 3) decrease from east to west in the Tahoua region from 350 meters to -550 meters altitude. This confirms the increase in catchment depths from east to west, which can be explained by the topography of the area and the geometry of the Iullemeden basin [1].

These large water catchment depths in the central and western part of the region constitute a major obstacle to access to these resources by the population, as they do not have the means to realize and maintain this type of structure. However, these great depths ensure the sustainable protection of water resources against various pollution.

\subsubsection{Nature Lithology and Reservoir Power}

The lithologic formation of the Continental Hamadien Reservoir, marked in red (Figure 4 and Figure 5), is essentially composed of medium to coarse sandstones,

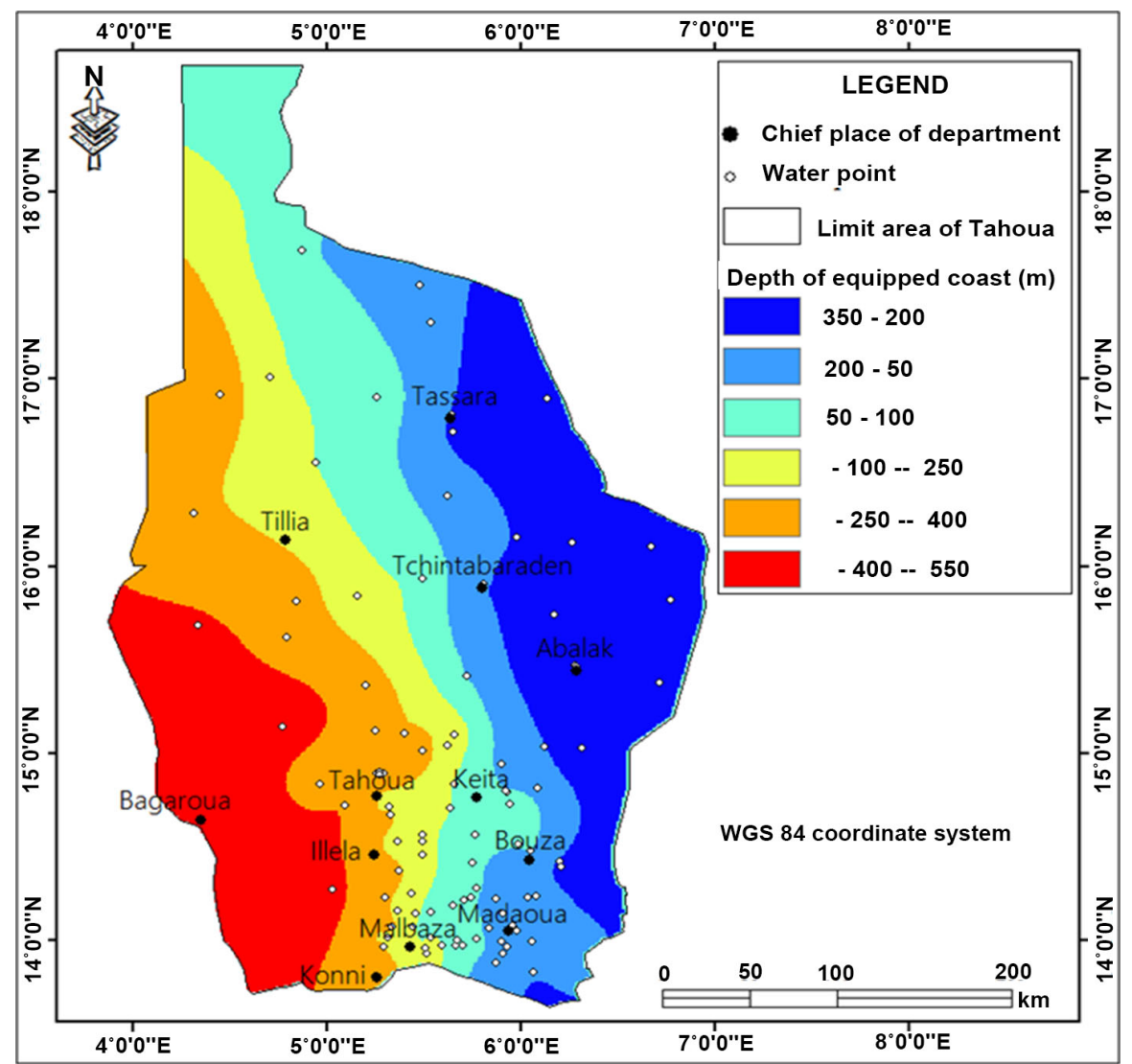

Figure 3. Map of depths equipped with boreholes capturing the $\mathrm{CI} / \mathrm{CH}$ aquifer system. 


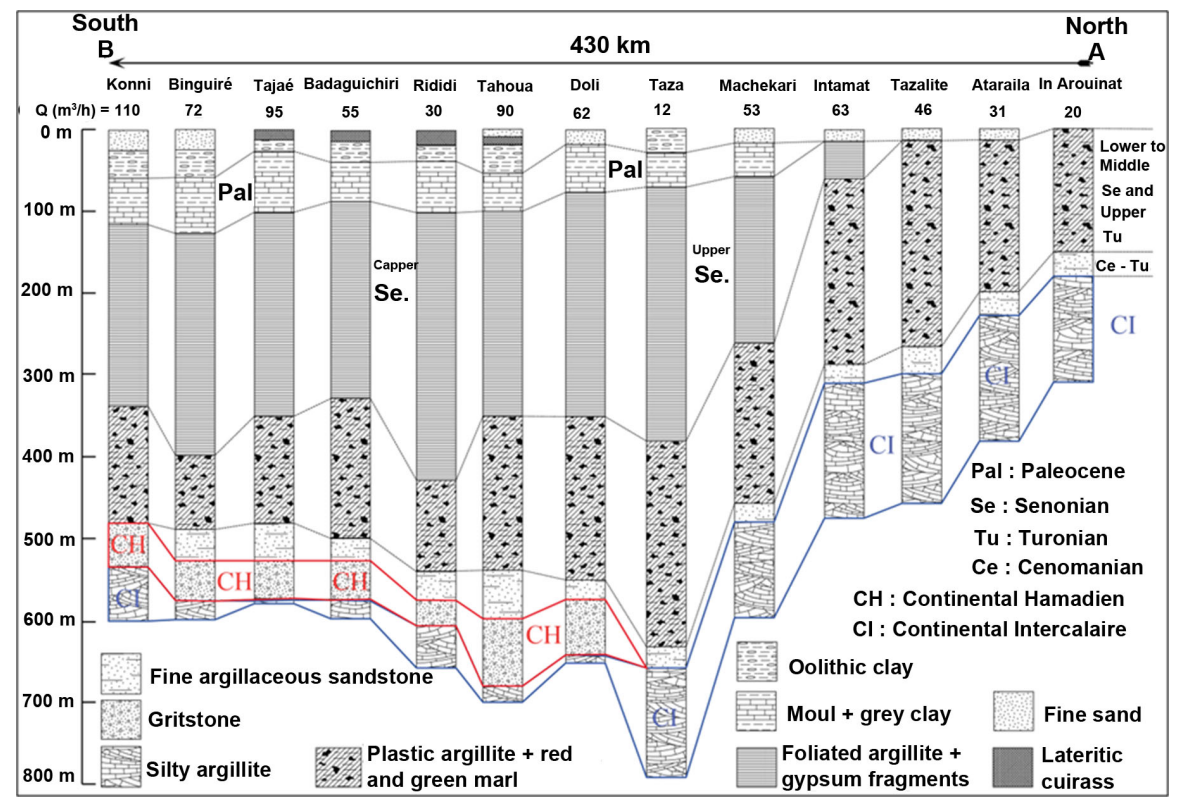

Figure 4. Lithologic boreholes with litho-stratigraphic correlations in the Tahoua region (South to North direction).

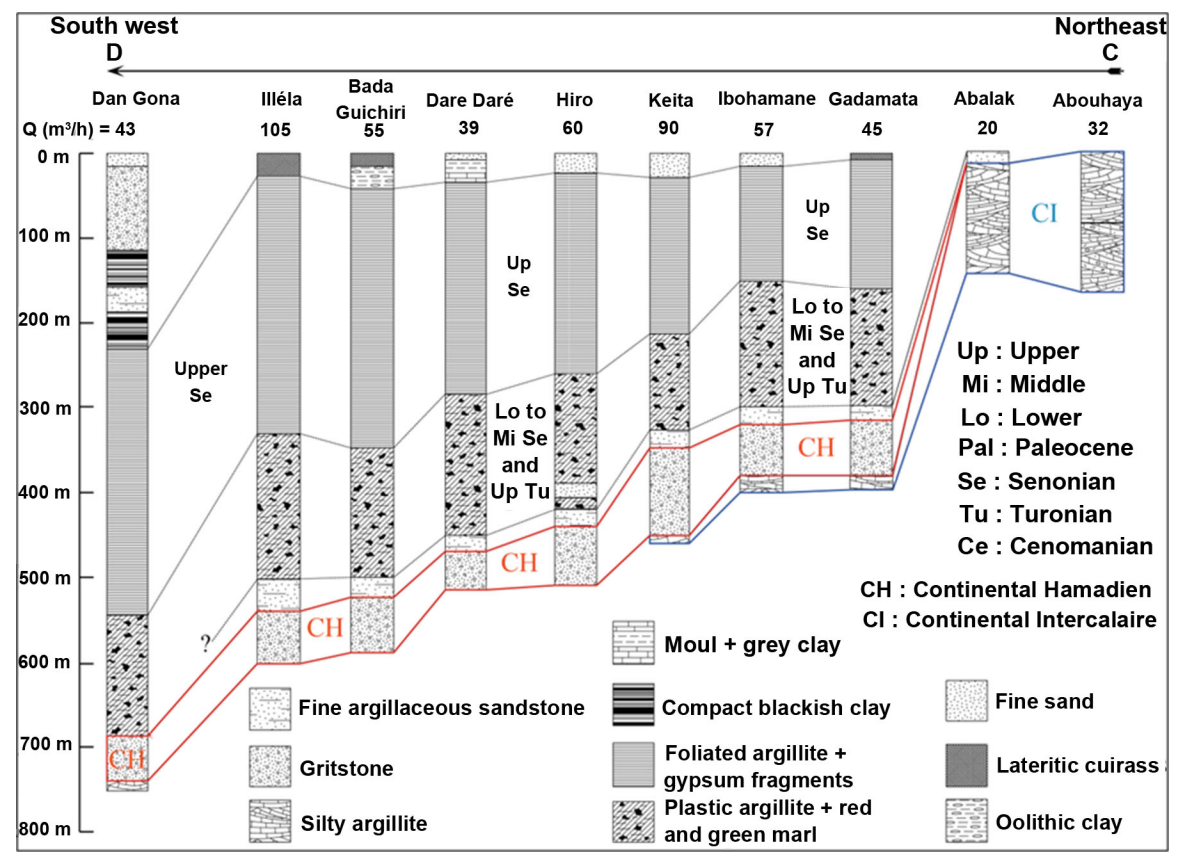

Figure 5. Lithologic boreholes with litho-stratigraphic correlations in the Tahoua region (direction SW-NE).

washed sand with quartz elements, very little clay sands and locally silts. This reservoir exists only in the southern part of the Tahoua region, where its average power is about fifty meters. As for the reservoir of the Continental Intercalaire, mark in blue (Figure 4 and Figure 5), present both in the part north than in the south, is in the form of a multilayer aquifer system. The lithological nature of this reservoir consists mainly of clayey sandstones, sandy clays, clay silts and sil- 
ty clays. The CI wall has never been reached by the various boreholes in the area, therefore, the reservoir capacity remains unknown.

The correlation between the different logs (Figure 4 and Figure 5), according to profiles A - B and C-D (Figure 2), shows that:

- The aquifers of the $\mathrm{CH}$ and these of $\mathrm{CI}$ were supported by the same types of geological formations namely the Turonian and Senonian;

- The $\mathrm{CH}$ groundwater table is absent in the northern part of the Tahoua region, which could be explained by the fact that at the time when the continental deposits continued in the southern part, the northern part was already suffering the effects of marine transgressions;

- Drilling catchment depths in the $\mathrm{CH}$ increase from northeast to southwest. In the CI, they increase from east to west and from north to south.

\subsection{Hydrodynamic Parameters}

\subsubsection{Static Levels}

The static levels of the $\mathrm{CI} / \mathrm{CH}$ aquifer system in the study area showed that:

- Groundwater collection depths were between 66 and 799 meters and static levels were between 3 meters above and 266 meters below the ground surface, with an average of 66 meters $(n=170)$. These results showed that the system was a loose web, with a captive groundwater table and an artesian captive groundwater table.

- Areas of artesianism (Figure 6) were located in low elevation areas when the aquifer was captive. They corresponded to areas located between $13^{\circ} 50^{\prime}$ and $14^{\circ} 50^{\prime}$ north latitude and $4^{\circ}$ and $4^{\circ} 7^{\prime}$ east longitude, in the departments of Birni N'Konni, Illéla and Malbaza and the border between Niger and Mali, a little north of latitude $17^{\circ}$ north. It should be noted that, outside the study area, several other areas of artesianism have been identified in the $\mathrm{CI} / \mathrm{CH}$ aquifer system, these were the Filingué, Birni and Lokoko zones [1] [22] [24] [18].

\subsubsection{Piezometric Map of the $\mathrm{CI} / \mathrm{CH}$ Aquifer System}

The piezometric map (Figure 7), of the $\mathrm{CI} / \mathrm{CH}$ aquifer system, shows that the aquifers have simple and regular piezometric surfaces over the entire region. This regularity of the piezometric surface for these two aquifer complexes is explained by the fact that the $\mathrm{CI}$ and $\mathrm{CH}$ layers were supported by the same types of formations, namely the Turonian and Senonian formations (Figure 4 and Figure 5).

However, it should be noted that despite this concordance of the piezometric level, the chemistry of the aquifer system remains heterogeneous between the $\mathrm{CI}$ and $\mathrm{CH}[4]$ [25].

The isopipe curves (Figure 7) decrease in altitude from east to west in the region from 390 to 280 meters, thus defining two main flow directions for the waters of the $\mathrm{CI} / \mathrm{CH}$ aquifer system of the region of Tahoua. One of the water flow directions, north of latitude $15^{\circ}$, has an east-west direction, while the other direction of flow, south of latitude $15^{\circ}$, north-trending. towards southwest. These 


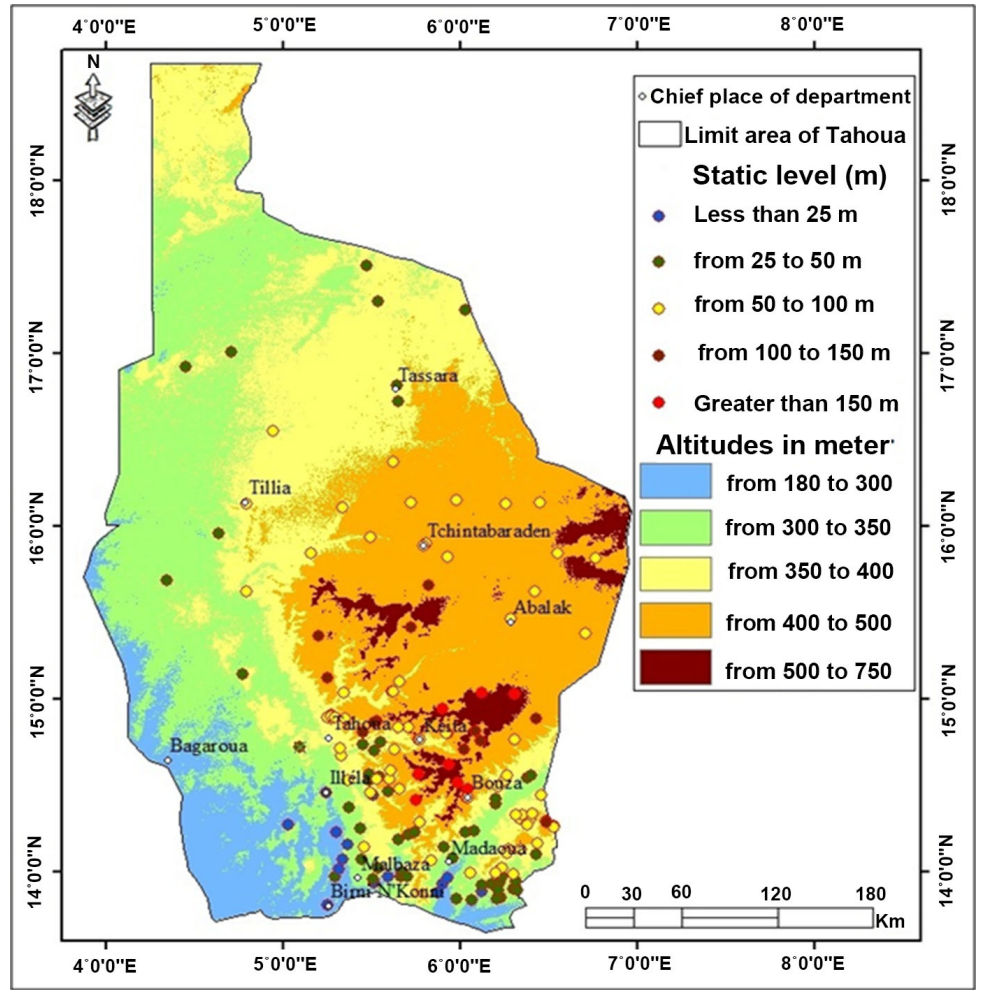

Figure 6. Topographic map and depths of static levels in the $\mathrm{CI} / \mathrm{CH}$ aquifer system of the Iullemeden basin (Tahoua).

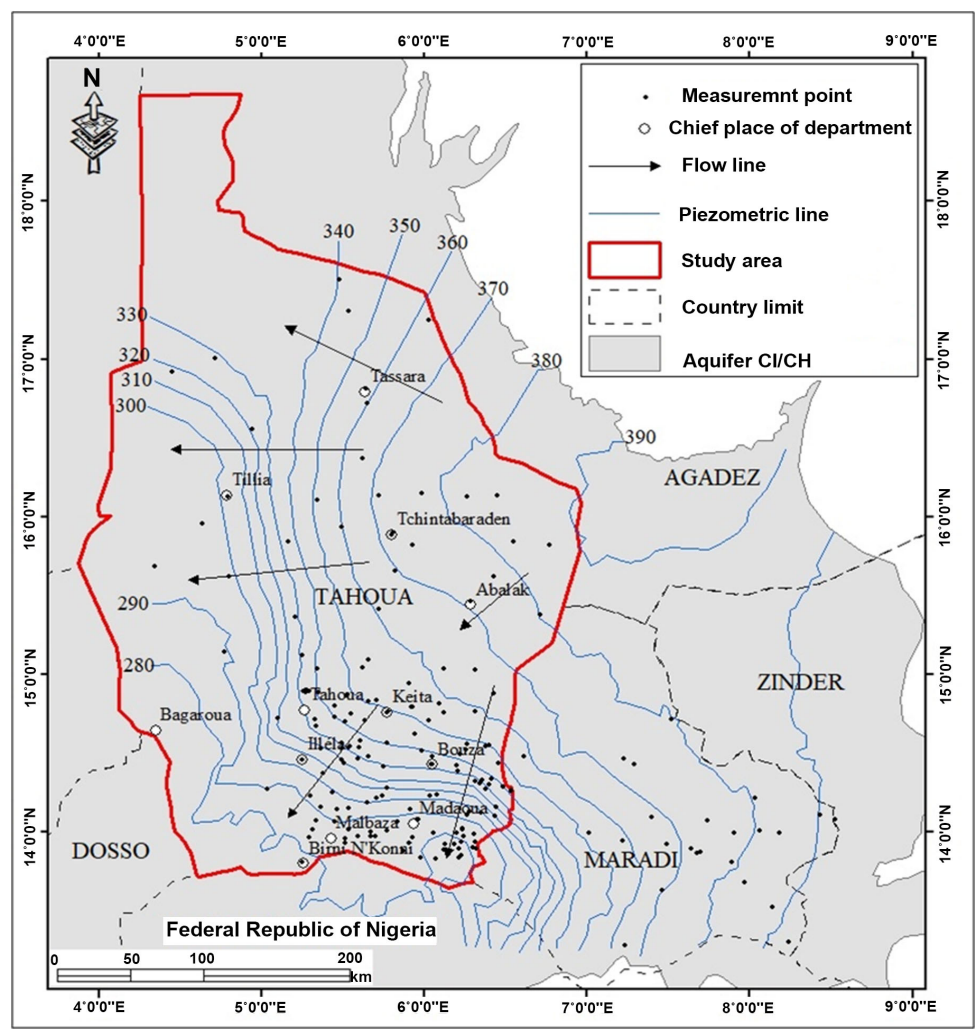

Figure 7. Piezometric map of the $\mathrm{CI} / \mathrm{CH}$ aquifer system of the Iullemeden basin (Tahoua). 
two main directions of flow converge towards the Niger River, these results are consistent with those of previous studies [1] [22] [26] [27].

In most of the northern sectors of the region, specifically in the Tassara department, the piezometric surface of the Continental Intercalaire aquifer is above that of the surface aquifers, thus favoring the construction of boreholes, that is to say wells powered by drilling.

\subsubsection{Specific Flows}

The specific flow rates (Qsp), of the Continental Intercalaire/Continental Hamadien of 120 boreholes in the Tahoua region, vary from $0.2 \mathrm{~m}^{3} / \mathrm{h} / \mathrm{m}$ to 22.8 $\mathrm{m}^{3} / \mathrm{h} / \mathrm{m}$, with an average of $7.2 \mathrm{~m}^{3} / \mathrm{h} / \mathrm{m}$, and a standard deviation of $4.8 \mathrm{~m}^{3} / \mathrm{h} / \mathrm{m}$. This highlights the importance of the water potential of $\mathrm{CI} / \mathrm{CH}$.

The spatial distribution map of the specific flow rates (Figure 8) shows a great heterogeneity between the $\mathrm{CI}$ and the $\mathrm{CH}$, this could be explained by the lithologic difference of these two reservoirs (Figure 4 and Figure 5). In fact, the highest specific flows were observed in the southern part of the region, where the $\mathrm{CH}$ groundwater table is captured, unlike the northern part where it is the CI that is captured, where the specific flows are lower.

\subsubsection{Coefficients of Transmissivity}

The transmissivity coefficients of the nine new drillings determined according to the examples of some diagrams (Figures 9-11) were between $2.3 \cdot 10^{-4}$ and $4.8 \cdot 10^{-2} \mathrm{~m}^{2} / \mathrm{s}$ (Table 1 ). These transmissivity values and those of the old boreholes, a total of seventy-two, range from $2 \cdot 10^{-4}$ to $2 \cdot 10^{-1} \mathrm{~m}^{2} / \mathrm{s}$, with an average of $2 \cdot 10^{-2} \mathrm{~m}^{2} / \mathrm{s}$, and a standard deviation of $3 \cdot 10^{-2} \mathrm{~m}^{2} / \mathrm{s}$.

The spatial distribution of the different values of the transmissivity coefficients of the Continental Intercalaire/Continental Hamadien aquifer system (Figure 12) showed that they increase from north to south of the Tahoua region, from $2 \cdot 10^{-4}$ to $2 \cdot 10^{-1} \mathrm{~m}^{2} / \mathrm{s}$. Thus, it was found that the transmissivity coefficients of the CI aquifer system, north of the Tahoua region, were at least a factor 1 lower than those of the Continental Hamadien, collected in the southern part of the study area. This could be explained by the lithological nature of the reservoirs. These results are consistent with those of other authors [6] [10] [14].

\subsection{Flow Velocities}

From the Darcy equation, the groundwater flow velocities of the Continental Intercalaire and Continental Hamadien aquifer systems have been calculated and have values between 6 and $42 \mathrm{~m} /$ year. It can be noted that for the Continental Hamadien aquifer, the values were between 13 and $42 \mathrm{~m} /$ year, with an average of $29 \mathrm{~m} /$ year. While, for the Continental Intercalaire aquifer, these vary from 6 to 8 $\mathrm{m} /$ year, with an average of $7 \mathrm{~m} /$ year. It is noted that the groundwater flow velocities in the $\mathrm{CH}$ were of the order of four (4) times higher than those in the IC. This could be explained by the lithological nature of these aquifers, which would consist mainly of medium to coarse sandstones for the Continental Hamadien (south), and clayey sandstones and silty clay for the Continental Intercalaire 


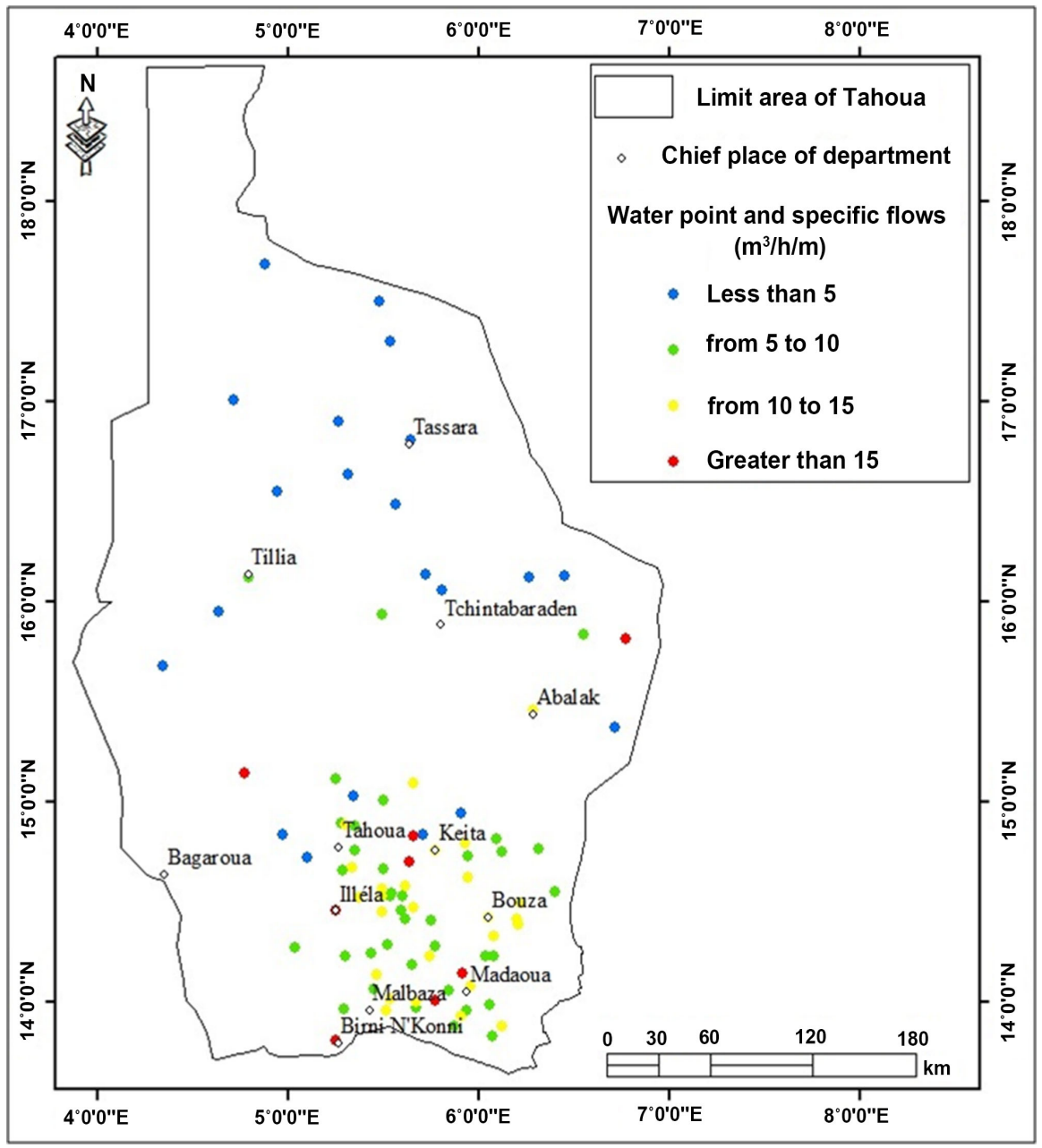

Figure 8. Spatial distribution map of Qsp specific flows in the $\mathrm{CI} / \mathrm{CH}$ aquifer system of the Iullemeden basin (Tahoua).

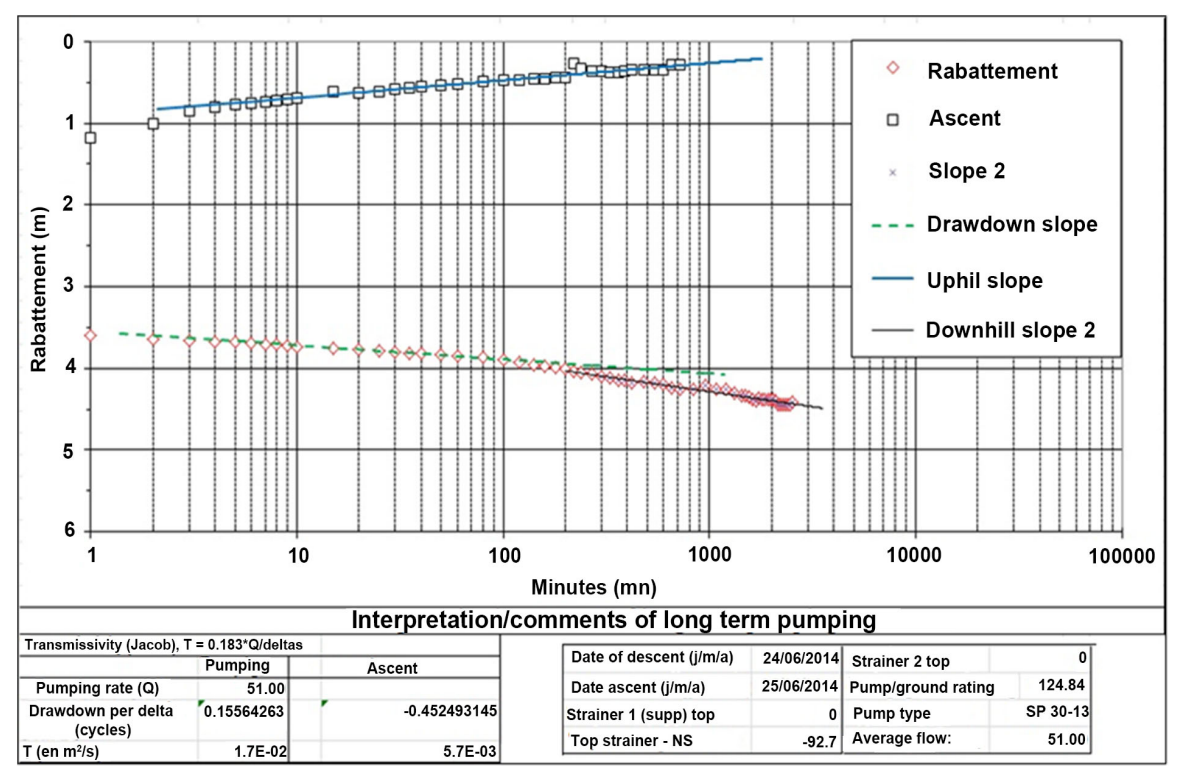

Figure 9. Long-term test pumping plug for Bouza SEEN drilling. 


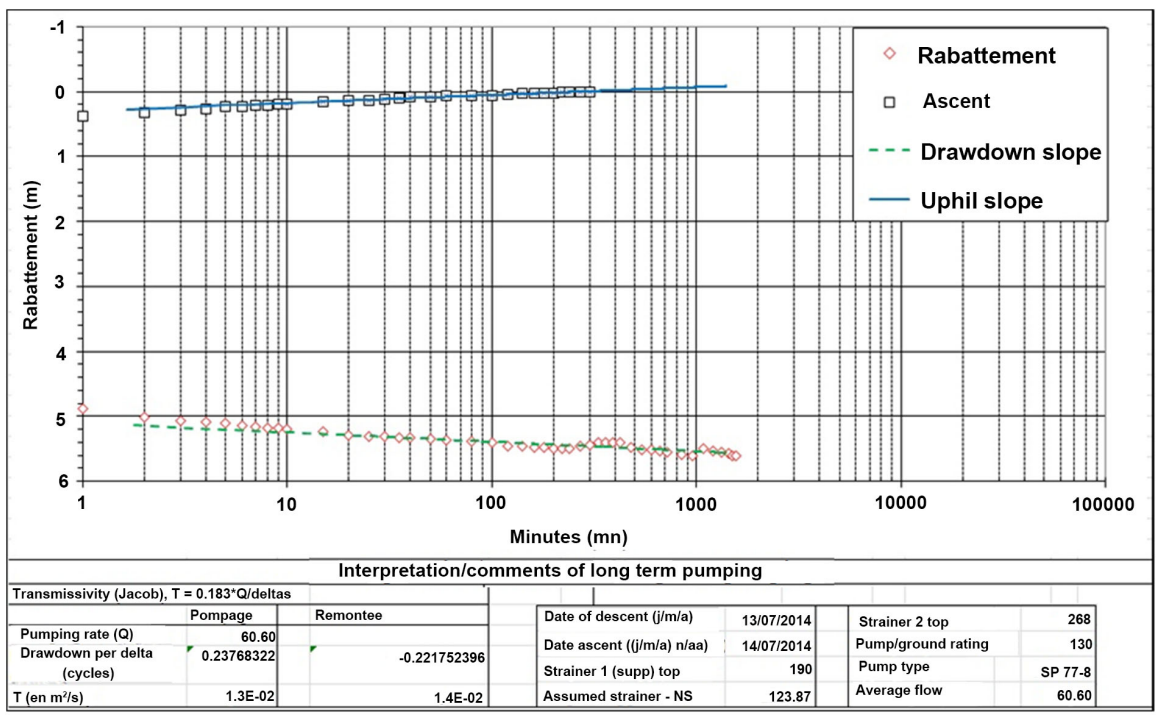

Figure 10. Keita SEEN long-term test pumping plug.

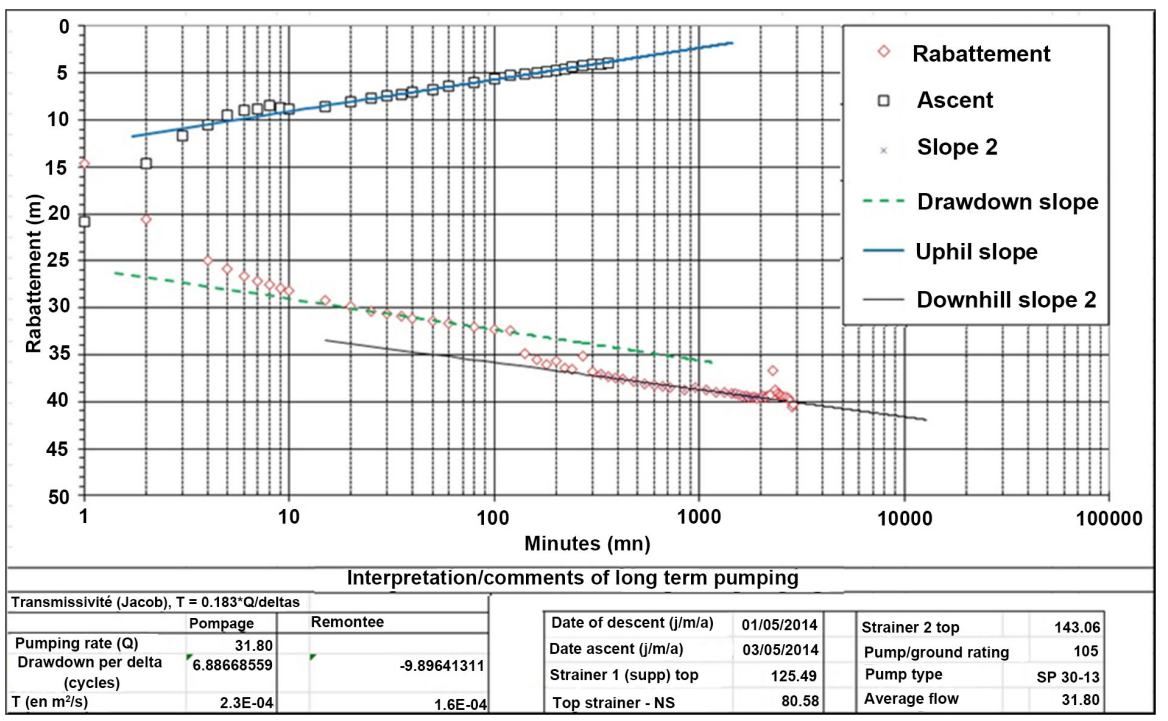

Figure 11. Long-term test pumping plug for Tassara SEEN drilling.

Table 1. Transmissivity coefficient values of the nine new boreholes [4].

\begin{tabular}{cccc}
\hline Site & Altitude & Longitude & Transmissivity \\
\hline Bouza SEEN & 6.044917 & 14.425861 & $1.70 \mathrm{E}-02$ \\
Doguéraoua SEEN & 5.592861 & 13.968861 & $1.80 \mathrm{E}-02$ \\
Ibohamane SEEN & 5.923028 & 14.794222 & $2.90 \mathrm{E}-02$ \\
Illéla SEEN & 5.246361 & 14.457056 & $1.80 \mathrm{E}-02$ \\
Keita SEEN & 5.76875 & 14.758306 & $1.30 \mathrm{E}-02$ \\
Konni SEEN & 5.248806 & 13.805944 & $4.80 \mathrm{E}-02$ \\
Takanamatt SEEN & 4.770111 & 15.142667 & $9.30 \mathrm{E}-03$ \\
Tamaské SEEN & 5.654028 & 14.829972 & $3.80 \mathrm{E}-02$ \\
Tassara SEEN & 5.643472 & 16.808361 & $2.30 \mathrm{E}-04$ \\
\hline
\end{tabular}




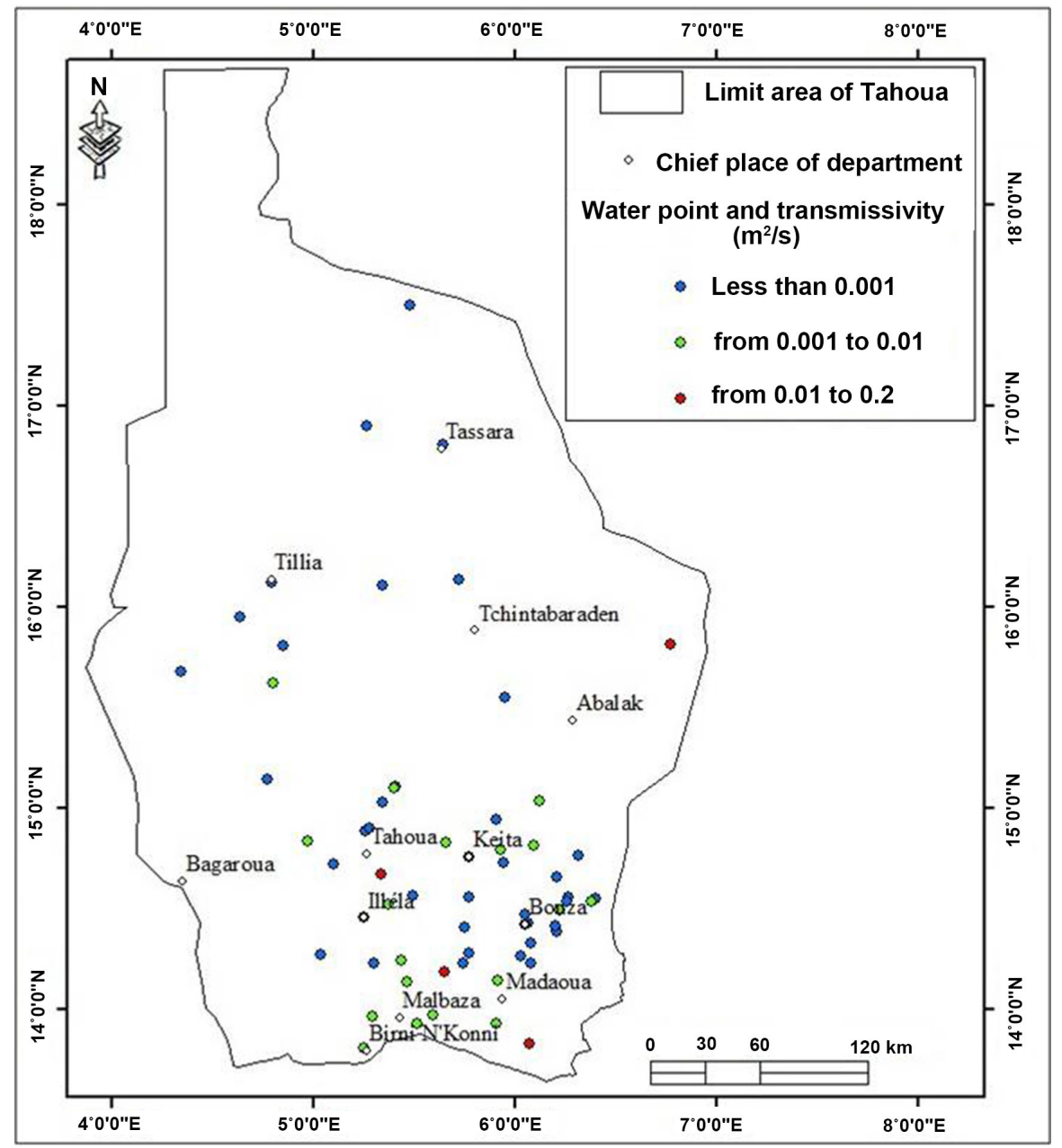

Figure 12. Spatial Distribution Map of Transmissivity Values in the CI/CH of the Iullemeden Basin (Tahoua).

(north) with poor hydrodynamic parameters. This is just to confirm the previous observations, on the fact that the tablecloths of the $\mathrm{CH}$ are more productive than those of the IC [1] [15] [18].

\section{Conclusion}

The main results obtained in this study were relatively numerous. The depths of groundwater collection were increasing from east to west in the Tahoua region, from less than 70 meters to more than 800 meters deep. This increase is mainly due to the geometry of the basin. The reservoir of the $\mathrm{CH}$, captured only in the south of the region, has an average thickness of 50 meters. On the other hand, the power of the IC, which is a multilayer system, is unknown because the wall has never been reached by the various structures. The two tanks of $\mathrm{CI} / \mathrm{CH}$ are pressurized by the same types of formations, namely the formations of Turonian and those of Senonian. The isopia curves were simple and regular, thus giving two main directions of flow to waters that were east-west and north-east to south-west, converging both to a single outlet on the Niger River. Specific flow 
rates, transmissivity and water flow rates were greater in the $\mathrm{CH}$ reservoir than in the IC reservoir. The results showed that the $\mathrm{CH}$ water table has the best hydrodynamic characteristics and a higher water potential than the IC. Finally, it is still necessary to continue investigations at the level of this aquifer, in order to better evaluate its potentialities for the sustainable management of these underground water resources.

\section{Acknowledgements}

The authors are grateful to the reviewers whose remarks and critics would certainly contribute to the amelioration of the quality of this paper.

\section{Conflicts of Interest}

The authors declare no conflicts of interest regarding the publication of this paper.

\section{References}

[1] Greigert, J. (1978) Atlas des eaux souterraines de la République du Niger. Etat des connaissances. Rapport BRGM, 79 AGE001, Orléans.

[2] Amadou, H., Laouali, M.S. and Manzola, A.S. (2014) Caractéristique hydrochimique des eaux souterraines de la région de Tahoua (Niger). Journal of Applied Biosciences, 81, 7161-7172. https://doi.org/10.4314/jab.v81i1.6

[3] Barrat, J.M. (2016) Ressources en eau des systèmes aquifères Iullemeden/Taoudéni/ Tanezrouft en Afrique Sahélo-Saharienne. Revue officielle de la société géologique de France, Géosciences appliquées, Numéro 191.

[4] Hassane Saley, A.K. (2018) Évaluation des ressources en eau de l'aquifère du Continental Intercalaire/Hamadien de la région de Tahoua (bassin des Iullemeden, Niger): Impacts climatiques et anthropiques. Thèse de doctorat, Université Paris-Sud et Université Abdou Moumouni de Niamey-Niger, 295 p.

[5] Sircoulon, J. (1976) Les données hydropluviométriques de la sécheresse en Afrique intertropicale. Comparaison avec les sécheresses 1913 et 1940. Cahier ORSTOM, série hydrologique, Volume 13, No. 2.

[6] Paturel, J.E., Servat, E., Travaglio, M., Ouedraogo, M., Boyer, J.F., Lubes-Niel, H., Fritsch, J.M., Masson, J.M. and Marieu, B. (1997) Identification, caractérisation et conséquences d'une variabilité hydrologique en Afrique de l'Ouest et centrale. ORSTOM, programme FRIEND AOC, 06 BP 1203; cedex 1, Abidjan 06-Côte d'Ivoire.

[7] Ardoin-Bardin, S. (2004) Variabilité hydroclimatique et impacts sur les ressources en eau de grands bassins hydrologiques en zone soudano-sahélienne. Thèse de doctorat, Université de Montpellier 2, 437 p.

[8] Ozer, P., Hountondji, Y.-C., Niang, A.J., Karimoune, S., Laminou Manzo, O. and Salmon, M. (2010) Desertification au Sahel: Historique et perspectives. BSGLg, 54, 69-84.

[9] Ozer, P., Bodart, C. and Tychon, B. (2005) Analyse climatique de la région de Gouré. Niger oriental: Récentes modifications et impacts environnementaux. $C y$ berGeo: European Journal of Geography, 308, 1-24.

https://doi.org/10.4000/cybergeo.3338 
http://cybergeo.revues.org/3338

[10] INS (2014) Le Niger en chiffre 2014. Edité par direction de la coordination et du développement de la statistique (DCDS). 128, rue de la Sirba, BP 13416, Niamey-Niger.

[11] Greigert, J. (1966) Description des formations crétacées et tertiaires du bassin des Iullemeden (Afrique occidentale). BRGM, Paris, 229 p.

[12] Dodo, A. (1992) Etude des Circulations Profondes dans le Grand Bassin Sédimentaire du Niger: Identification des aquifères et compréhension de leurs fonctionnements. Thèse de doctorat, Université Neuchatel-France, IGCH, 165 p.

[13] Guero, A., Marlin, C., Leduc, C. and Boureïma, O. (2003) Use of Environmental Isotopes $(18 \mathrm{O}, 2 \mathrm{H}, 3 \mathrm{H}, 14 \mathrm{C})$ and Hydrodynamic Modelling to Highlight Groundwaters Mixing in the South-Western Part of the Iullemmeden Basin (Niger). International Symposium on Isotope Hydrology and Integrated Water Resources Management, Vienne, IAEA-CN-104/38.

[14] OSS (2008) Gestion concertée des ressources en eau partagées d'un aquifère transfrontalier sahélien: Le Système Aquifère d'Iullemeden, synthèse no. 2. Rapport interne, Tunis, $20 \mathrm{p}$.

[15] MEELD (2010) Projet d'hydraulique villageoise dans la région de Tahoua: Réalisation de 24 forages profonds. $204 \mathrm{p}$.

[16] DRHAT (2008) Monographie de la région de Tahoua. 103 p.

[17] MHA (2014) Rapport sur les indicateurs de l'eau potable et de l'assainissement pour l'année 2013, du Comité technique permanent de validation des indicateurs de l'eau et de l'assainissement. République du Niger.

[18] SPEN (2015) Projet de renforcement et d'extension des réseaux d'AEP dans 18 centres secondaires de la SPEN: Travaux de réalisation, d'équipement et de raccordement de 20 forages gros diamètres. $66 \mathrm{p}$.

[19] OSS (2017) Gestion intégrée et durable des systèmes aquifères et des bassins partagés de la région du Sahel: Rapport du projet régional de coopération technique RAF/7/11, appuyé par l'AIEA. 118 p.

[20] FAO (1970) Etudes en vue de la mise en valeur du Dallol Maouri, Niger: Les eaux souterraines, cartes et graphiques. Rome, 281/NIR 8, 162 p.

[21] Greigert, J. and Pougnet, R. (1965) Carte géologique de la République du Niger au 1: 2000 000. BRGM, Paris.

[22] Guero, A. (2003) Étude des relations hydrauliques entre les différentes nappes du complexe sédimentaire de la bordure Sud-Ouest du bassin des Iullemmeden (Niger): Approches géochimique et hydrodynamique. Thèse de doctorat, Université Paris-Sud 11-Orsay, 265 p.

[23] Forkasiewicz, J. (1972) Interprétation des données de pompages d'essai pour l'évaluation des paramètres des aquifères. Rapport du B.R.G.M, aide-mémoire, 2ème édition. Département géologie de l'aménagement hydrogéologie.

[24] Favreau, G. (2000) Caractérisation et Modélisation d'une nappe phréatique en hausse au Sahel: Dynamique et géochimie de la dépression piézométrique naturelle du kori de Dantiandou (Sud-Ouest du Niger). Thèse de doctorat, Université Paris-Sud 11-Orsay, $353 \mathrm{p}$.

[25] Hassane Saley, A.K., Sandao, I., Michelot, J.-L. and Boureïma, O. (2019) Apport des paramètres physico-chimiques des eaux à l'amélioration de la connaissance de l'aquifère du Continental Intercalaire/Continental Hamadien de la région de $\mathrm{Ta}$ houa (Bassin des Iullemeden, Niger). European Scientific Journal, 15, 444-468. 
https://doi.org/10.19044/esj.2019.v15n12p444

[26] Margat, J. (1982) Aquifère du Continental Intercalaire du bassin sédimentaire du Niger (Mali, Niger, Nigéria). Bulletin, BRGM, Hydrogéologie, No. 2.

[27] OSS (2007) Modèle hydrogéologique du système aquifère d'Iullemeden (SAI). N $212,85 \mathrm{p}$. 